\title{
STUDY ON VESTIBULAR FUNCTION IN PUPILS OF PRIMARY AND SECONDARY SCHOOLS IN THE KANAGAWA PREFECTURE (FOURTH REPORT)
}

\author{
KOHJI TOKUMASU, M. D., KIMIHISA NOMURA, M. D., SUSUMU IIDA, M. D., \\ YOSHIKO KUSUNOKI, M. D., YOICHI TSUCHIDA, M. D., \\ HARUHIRO TANEMOTO, M. D., MOTOAKI ARAKI, M. D. \\ and MASAAKI MIYAHARA, M. D. \\ Kanagawa Division of Japan Otorhinolaryngological Saciety \\ (Director: Takashi, Hirose, M. D.)
}

\begin{abstract}
Eight thousands five hundreds and ninty-two pupils of 8 primary schools and 6 secondary schools in the Kanagawa prefecture had been examined by specially designed equilibrium function tests in a 4-year period from 1975 to 1978 . The equilibrium examinations included one foot standing test in foreward tilted posture with eyes opened, walking test with eyes closed, twice step-rotating test with eyes closed and modified Heath's rail-walking test. A balance board test was added in only 1978, since the boards are popular equipments in the schools in Japan. The mean value and standard deviation of each test result were evaluated.

The relationship between equilibrium function and the other related factors, such as sex, school grade, Rohrer's index, school records and answers to 15 questionaires about daily lives in each pupil was studied by using a FACOM 230-38 electronic computer.

The normal ranges of the test results reported in our previous papers were reconfirmed. It is assumed that each equilibrium function test might be important to find out the abnormality of equilibrium from different aspects and the test results are closely related to the labyrinthine function, vision, cerebellar motor function, autonomic nervous system, cardiovascular system and psychosomatic state in test subjects.
\end{abstract}

$\mathrm{A} 84-0024-24572$

\section{神奈川県における监童および生徒の平衡機能の調查（第 4 報）}

\section{4 年間 $の$ 調 查集計}

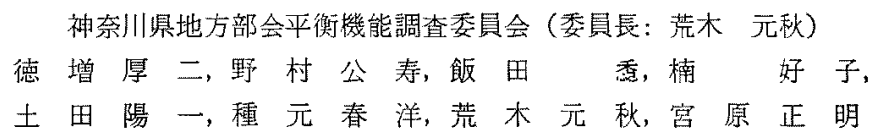

緒

論

心身の発達途上にある小・中学生の体力づくりは国の 将来の担い手を正しく育成するため深い成哭心持たれて
いる. 日本学校保健会，健康度評侐方法委貴会が提唱 し, 各小・中学校て実施している運動機能榆査 ${ }^{122}$ は運 動能力乞体力上を多面的に捉へ，それを評価するすのと 
して意義が深い，小・中学生の時期は身体の成舆と関係 $し て$, 自律神経系, 内分泌系の变化も著しく, ま知能 や運動の面の学習に重要な時期である。この年代に少な からずみられる起立性調節障害や動摇病などは身体の発 達過程でみられる自律神経系のアンバランスと関連があ り，運動機能は身体の平衡機能の面からも検討される必 要がある。

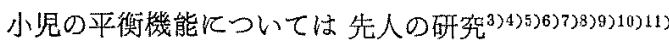
12) があるが，その重要性についての認識は現在な括十 分であるとはいいがたい。

神奈川県地方部会平衡機能調查委員会 (委員長 荒木 元秋）は昭和50年より, 神奈川県下の一部の小・中学生 を対象飞, 一定の平衡機能桧査索実施し, 関連する他の

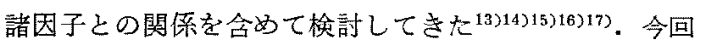
は今までの調査結果に基いて調査方法を一部变更した昭 和 53 年度の 調查結果上と屯に, 昭和 50 年上り 昭和 53 年 までの 4 年閒の 8,592 名の小・中学生を対象とした 調 査結果のまとめを報告する. 前回と同様 資料は電算機 FACOM 230-38 で処理し解析した.

\section{調 查 対 象}

調査を実施した学校は神奈川県の平塚市, 横須賀市, 相模原市飞血る8 小学校と6中学校の先童・生徒であ る. 昭和年53度小学生 1,556 名, 中学生 481 名（男子 1，054名，女子983名）が加えられ昭和50年より昭和53年 まての 4 年間で, 小学生 6,343名, 中学生 2,249名 (男 子 4,479名, 女子 4,113名) 計 8,592 名を調查刘象之し た.

崇善, 土屋, 松原, 南原, 走水, 船越, 麻溝の 7 小学 校と, 大住, 金旭, 春日野, 鸭居, 共和の 5 中学校沉, 昭和53年度は横須賀市立の馬堀小学校と田浦中学校とが 加光られた。各年度の調査対象者数は次の通りである。

昭和50年度 小学生男子 797 , 女子 758 , 中学生男子 306, 女子 285

昭和 51 年度 小学生男子 834 , 女子 751 , 中学生男子 300 , 女子 285

昭和52年度 小学生男子 888 , 女子 757 , 中学生男子 300 , 女子 292

昭和 53 年度 小学生男子 809 , 女子 749 , 中学生男子 245 , 女子 236

調查項目, 調查方法

1. 平衡機能検査の種類と判定方法
平衡機能検査は飛行機型単脚起立㭘查, 歩行検査, 2

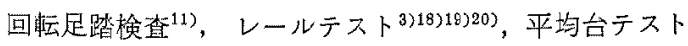
の5種目を実施した。 †で飞報告した結果 ${ }^{13) 153177}$ 亿基い て, 昭和53年度の検查で単脚起立検查の起立時間を従 来の30秒より60秒まで延長し，2 回転足踏娭査ては右 回転, 左回転加占右回枟のみとした，規格の平均台を使 用する平均台テストを新らたに加えた。判定基準はすで 飞報告した基準 ${ }^{77}$ 飞従った。

1) 飛行機型単脚起立喻査

開眼, 片足立ちで両側上肢を左右八水平飞挙上し，上 体をほほ $45^{\circ}$ 前傾し，挙上足を後方八伸展する.この姿 勢を60秒までとらせ，もし途中で挙上足が接地すれば接 地までの時閏を測定する。

2) 歩行检查

遮眼で前方へ真直ぐ $6 \mathrm{~m}$ 両手を軽くふりながら歩行す

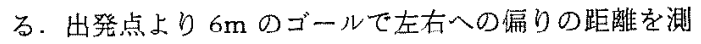
定する。

3） 2 回転足踏模查

遮眼で直立し，両側上抆を前方へ水平化伸展し，同じ 地点で足を高くあげながら右方向へ足踏をし，ほほ20歩 で2回枟してもとの位置にもどる. 足踏終了後, 出発時 の足跡からのずれの距離と偏位角度を測定する.

ず机出発点を中心とした半径 $15 \mathrm{~cm}, 25 \mathrm{~cm}, 35 \mathrm{~cm}$ の円内と，35cm の円外の各区域にかかとがある時をそ れぞれ 1，2，3４４ゾーンとする．偏位角は過不足を問 わず，出発時江対する終了時の体の向きの角度を絶対值 であらすす。

4) レールテスト

開眼, 裸足でテスト台上を端から粎歩歩行でゆっくり 歩く. 歩行時上肢の運動, 稫幹の姿勢は自由てよい、テ ス卜台は幅 $5.0 \mathrm{~cm}$, 高さ $7.5 \mathrm{~cm}$, 辰さ $270 \mathrm{~cm}$ の木箐台 で $30 \mathrm{~cm}$ 間隔に印がつけられている，検査は 2 回施行し， 落下時までに歩行出来た区画数の合計に $10 / 9$ 老乗し測

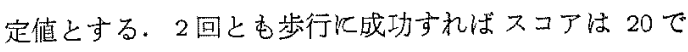
ある.

\section{5）平均台テス卜}

平均台を用いてレールテストと同じ要領で模査をおこ なう、平均台は規定により幅は $10 \mathrm{~cm}$, 高さは小学校 $1 \sim 3$ 年生では $30 \mathrm{~cm}$, 小学校 $4 \sim 6$ 年生では $55 \mathrm{~cm}$, 中学生では $80 \mathrm{~cm}$, 長さは 小学生では $360 \mathrm{~cm}$, 中学生

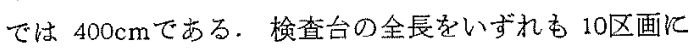

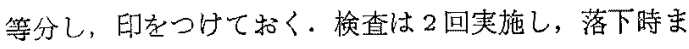
で歩いた全区画数の合計を求める，2回とも歩行に成功 
すればスコアは 20 である.

\section{2. 学業, 体育成績などの調查}

すへての平衡機能検査被検者について所属学校名, 学 年, 性別, ローレル指数, 学業成績, 体育成績を調查し た. 2 小学校高学年と 2 中学校ではスポーッテストの成

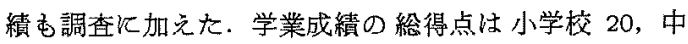
学校は 25 であり, 体育成績は小・中学校共に 5 段階評 価である、スポーツテストは運動能力テストと体力診断 テストからなる，運動能力テストでは $50 \mathrm{~m}$ 走, 走り幅 跳び，ソフトボール投げ，斜め慜垂，ジグザグドリブ ル，連続逆上がりの5 種目で，総得点は 100であり1〜 5 級にわかれる.体力診断テストは反復横跳び, 垂直跳 び, 背筋力, 握力, 上体そらし, 体前届, 踏台昇り降り の 7 種目で, 各種目は 5 段階評価で，総得点は 35 であ り $\mathrm{A} \sim \mathrm{E}$ 級沉わかれる゙2.

3. アンケート調查

昭和 53 年度は昭和 52 年までのアンケート調査 ${ }^{16)}$ を整理 し 項目として, 記入方法は小学校低学年は父母の助け を借りて，他は本人に記入させた。また新しく担任教諭 に記入を求める8項目のアンケートを加えた。いつれも 平衡機能と学校調查の結果との関連性が予想される質問 がとりあげられた.アンケート内容は表 1 飞示す 本人 用は１）起立時の異常，2）動悸，息切れ，3）立ちくら み，4）乗物醉い，5）中耳炎の既往，6）自転車飞乘れ
る，7）課外スポーツについて，担任用は 8）聼力，9） 視力，10）乘物醉い，11）起立時異常，12）枟倒傾向, 13）球技が得意，14）情緒異常，15）食物の好き嫌い, とついての質問である.

\section{調 查 結 果}

1. 昭和 53 年度平衡機能㭘查成續

飛行機型単脚起立検查, 歩行検査, 右 2 回転足踏検查, レールテスト，平均台テストの 5 種目の平衡機能検查測 定值の学年別, 性別の平均值と標準偏差 SD を表 2 亿示 †.

2. 昭和 53 年度学校調查結果

平衡機能㭘查を実施した全員のローレル指数, 学業成 績, 体育成精と 2 小学校高学年児童と 2 中学校生徒飞つ いて運動能力テストと体力診断テストの学年别ならびル 性別の平均値々標準偏差を表 3 亿示す

3. 4 年間の平衡機能検査結果の比較

小・中学生の昭和 50 年より昭和53年までの各年毎の口 ーレル指数と各平衡機能検査結果の平均值と祭準偏差を 表 4 亿示す

昭和53年度は 2 回転足踏検查怯右回転のみとし，また 単脚起立検查時間は昭和 50 年より昭和 52 年までは30秒ま で，昭和53年は60秒までとした。

4. 平衡機能檢查成績の正常・異常の判定

表 1 平衡機能検查用アンケート

1 7 : 本人用

1. 長時間立っていると気持が悪くなり，それが ひどくなって倒れることがありますか。

2. 少し動くと心瀻がドキドキしたり息切れがし たりしますか。

3. 坐っていて急泣ったとさ，フラッとするこ とがありますか。

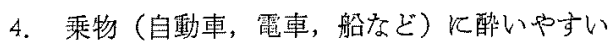
ですか。

5. 中耳炎飞加加たことがあり忠す加。

6. 自転車に乘狆ますか（小学校 4 年以上）

7. 課外スポーツ（球技, 水泳, スキ一, スケ一 卜，柔・剣道など)、舞踊などるしていますか。
$8 \sim 15$ : 担任用

8. 教室で座席の配煘なく普通の大きさの声がき こ充ます力.

9. 黑板の字方座席の配慮なくよ?見立ますか （眼鏡を必要なすのはこれを装用して）。

10. 修学旅行などでバス, 電草, 船などに既った ことがありますが。

11、朝礼のときなどに気持が覀くなり倒れたこと があり亦す亦。

12. 走ったとき転びやすいですか，

13.*球技(ドッヂボール，サッカーなど）㥂意 ですか。

14. 兔強ぎらい，根気がない，登校拒否なビがあ ります力。

15、殓食の食べ残しが多いですか. 
表 2 昭和53年度平衡機能检查学年別, 性別成綪

$\mathrm{A}$ : 飛行機型単脚起立検查 起立持続時間 60 犁まで $\mathrm{B}$ : 步行検查 偏倚距離 $\mathrm{cm}$ $\mathrm{C}$ ：右 2 回忶足踏検植ずれ ゾーン $1 ; 15 \mathrm{~cm}$ 末満 $2 ; 15 \sim 25 \mathrm{~cm}$ 未満 $3 ; 25 \sim$ $35 \mathrm{~cm}$ 末満 4; $35 \mathrm{~cm}$ 以上 $\mathrm{D}$ ：右 2 回枟足踏模查 偏位角度絶対值 $E$ ：レー ルテスト 総点 $20 \mathrm{~F}$ : 平均台テスト 総点 20

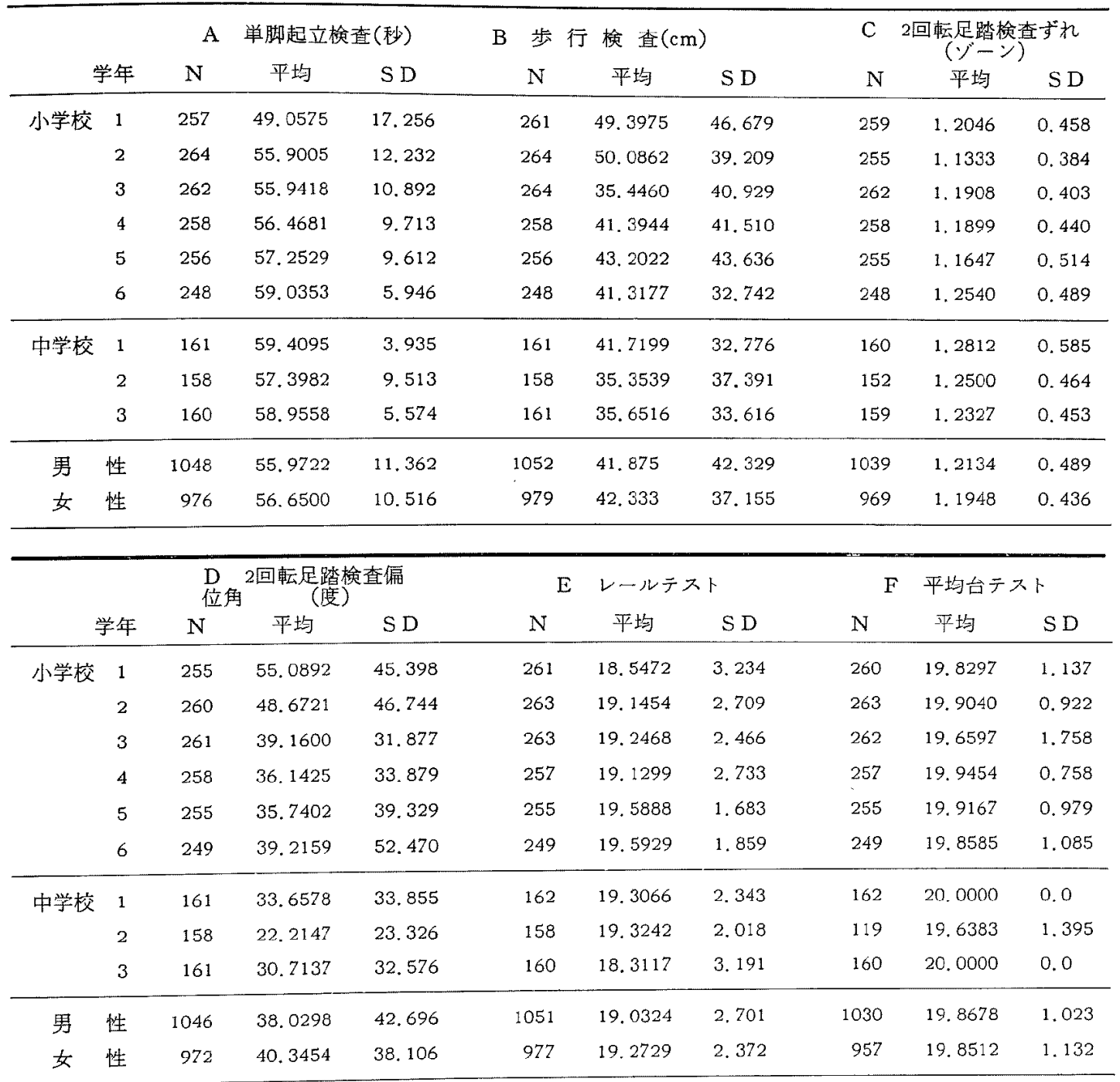

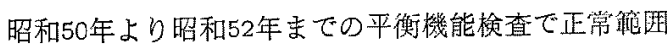
を標準值で定めたと報告した ${ }^{17)}$.

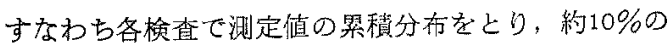
成績不良のものをの亮いた測定值を標準值とした，各检 查で定めた標隻值は次の通りである。

飛行機型単脚起立では60梨，步行検查偏倚距離は 130 cm以内，レールティトでは 12 以上， 2 回轱足踏検查で は移行距睢（ずれ）は 2 ゾーン (15より $25 \mathrm{~cm}$ ) 以内， 偏位角度は $135^{\circ}$ 以内とした，今回 あらた飞加光た平均 台テストでは 20 とした。

昭和53年平衡機能㮔查成績の累積分布図と標準值を図

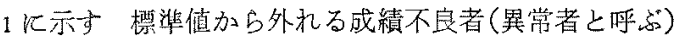


表 3 昭和 53 年度学校調査学年別・性別成績

$\mathrm{A}$ : ローレル指数 体重 $\mathrm{kg} \times(\text { 身長 } \mathrm{cm})^{-3} \times 10^{7} \mathrm{~B}$ : 学業成績 総点 小学生 20 , 中学生 $25 \mathrm{C}$ : 体育成績 小中学生共 5 段階評価 $\mathrm{D}$ : 運動能力テス卜総点 100 $\mathrm{E}$ : 体力診断テスト 総点 35

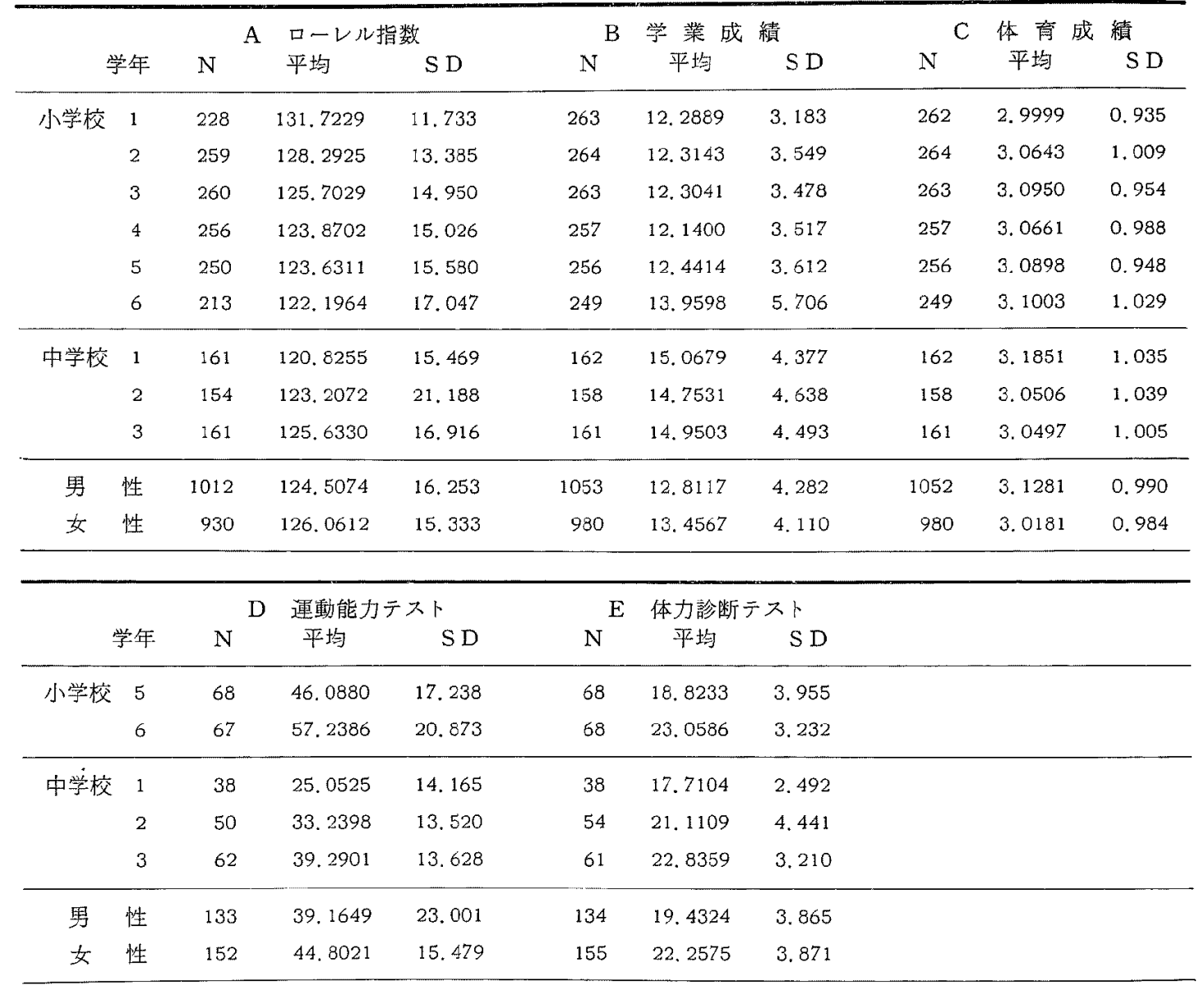

の絵数に対する百分率（図 1 の黑い部分, 単脚起立の黑

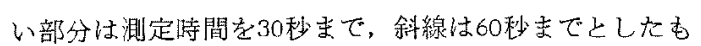
の) は単脚起立検查では $13.6 \%$ ，步行検查では $2.4 \%$, レールテストでは 3.4\%, 平均台テストでは $2.3 \%, 2$ 回転足踏検查でのずれは $1.6 \%$ ，惼位等度は $1.8 \%$ であ った.

5. 平衡機能検查成續と学校調查結舆との相関

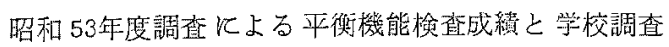
結果上の間の相間係数マトリックスを作成した. 総数 1,855例飞ついて 有意な相閜係数（p<0.001）のみを表 不声
小学校 5, 6 年生上中学生の 244例につWて, 㞄動能 力テスト、体力診断テストの成績, 学年, 性, 体有成績 との相互閏て，有意な相関係数 $(\mathrm{p}<0.001)$ のみを表右 上に示すな招スポーツテストと平衡機能検査成績の間 には有意な相関は得られなかった。

6. 各平衡機能検查の正常群, 異常群の比較

昭和53年度の調查值を, 栖染値で定めた各平衡機能検 查の正符群と異常群とにわけ，それぞれの群の学校謂査 船果拈よび, 他の平衡機能捨查成績の平均值を求め裴 6 に示し樱。

表 60 *印は各平衡機能検查の正常群上異常群之で求 
表 4 平衡機能换查小・中学校别成縝 昭和50年〜昭和53年の比校 点数は表 2 亿同じ*昭和53年のみ判定は60䟞まで，他は30秒まで

\begin{tabular}{|c|c|c|c|c|c|c|c|c|c|}
\hline \multirow[b]{2}{*}{ 椧查項目 } & \multirow[b]{2}{*}{$\begin{array}{r}\text { 检査年 } \\
\text { 総数 } \\
\end{array}$} & \multicolumn{2}{|c|}{ 小 } & \multicolumn{2}{|l|}{ 学 } & \multicolumn{2}{|c|}{ 中 } & 学 & \multirow{2}{*}{$\begin{array}{c}\text { 生 } \\
\text { 昭和53年 } \\
481\end{array}$} \\
\hline & & $\begin{array}{c}\text { 昭和50年 } \\
1555\end{array}$ & $\begin{array}{c}\text { 昭和51年 } \\
1585 \\
\end{array}$ & $\begin{array}{c}\text { 昭和52年 } \\
1647 \\
\end{array}$ & $\begin{array}{c}\text { 昭和53年 } \\
1556\end{array}$ & $\begin{array}{c}\text { 昭和50年 } \\
591 \\
\end{array}$ & $\begin{array}{c}\text { 昭和 } 51 \text { 年 } \\
585 \\
\end{array}$ & $\begin{array}{c}\text { 昭和 } 52 \text { 年 } \\
592 \\
\end{array}$ & \\
\hline ローレル指数 & $\begin{array}{l}\text { 平均 } \\
\text { S D }\end{array}$ & $\begin{array}{l}29.03 \\
14.40\end{array}$ & $\begin{array}{r}125.69 \\
13.60\end{array}$ & $\begin{array}{l}125.80 \\
14.37\end{array}$ & $\begin{array}{r}125.91 \\
14.99\end{array}$ & $\begin{array}{r}123.76 \\
16.73\end{array}$ & $\begin{array}{r}124.23 \\
16.94\end{array}$ & $\begin{array}{r}122.48 \\
15.20\end{array}$ & $\begin{array}{r}123.22 \\
18.04\end{array}$ \\
\hline レールテスト & $\begin{array}{l}\text { 平均 } \\
\text { S D }\end{array}$ & $\begin{array}{l}18.20 \\
3.63\end{array}$ & $\begin{array}{l}\text { 18. } 15 \\
\quad 3.74\end{array}$ & $\begin{array}{l}\text { 18. } 23 \\
\quad 3.77\end{array}$ & $\begin{array}{l}\text { 19. } 21 \\
2.40\end{array}$ & $\begin{array}{l}18.75 \\
\quad 3.24\end{array}$ & $\begin{array}{l}18.47 \\
\quad 3.40\end{array}$ & $\begin{array}{l}\text { 18. } 50 \\
\text { 3. } 47\end{array}$ & $\begin{array}{r}18.98 \\
2.60\end{array}$ \\
\hline 右回転検査ずれ & $\begin{array}{l}\text { 平均 } \\
\mathrm{SD}\end{array}$ & $\begin{array}{l}1.22 \\
0.62\end{array}$ & $\begin{array}{l}1.14 \\
\quad 0.40\end{array}$ & $\begin{array}{l}1.15 \\
0.39\end{array}$ & $\begin{array}{l}1.19 \\
0.45\end{array}$ & $\begin{array}{l}1.19 \\
0.42\end{array}$ & $\begin{array}{l}1.17 \\
0.44\end{array}$ & $\begin{array}{l}1.11 \\
0.38\end{array}$ & $\begin{array}{l}1.25 \\
0.50\end{array}$ \\
\hline 右回枟㭘査角度 & $\begin{array}{l}\text { 平均 } \\
\mathrm{SD}\end{array}$ & $\begin{array}{l}79.85 \\
177.19\end{array}$ & $\begin{array}{l}59.01 \\
89.24\end{array}$ & $\begin{array}{l}57.78 \\
85.45\end{array}$ & $\begin{array}{l}42.34 \\
42.69\end{array}$ & $\begin{array}{l}39.72 \\
51.32\end{array}$ & $\begin{array}{l}40.59 \\
61.36\end{array}$ & $\begin{array}{l}43.04 \\
\quad 49.70\end{array}$ & $\begin{array}{l}28.90 \\
30.65\end{array}$ \\
\hline 左回転桧査ずれ & $\begin{array}{l}\text { 平均 } \\
\mathrm{SDD}\end{array}$ & $\begin{array}{l}1.25 \\
0.51\end{array}$ & $\begin{array}{l}1.18 \\
0.43\end{array}$ & $\begin{array}{l}1.18 \\
0.42\end{array}$ & & $\begin{array}{l}1.19 \\
0.44\end{array}$ & $\begin{array}{l}1.19 \\
0,43\end{array}$ & $\begin{array}{l}1.13 \\
0.37\end{array}$ & \\
\hline 左回転検查角度 & $\begin{array}{l}\text { 平均 } \\
\text { S D }\end{array}$ & $\begin{array}{l}83.33 \\
161.17\end{array}$ & $\begin{array}{l}61.99 \\
94.49\end{array}$ & $\begin{array}{l}61.77 \\
86.73\end{array}$ & & $\begin{array}{l}41.31 \\
50.96\end{array}$ & $\begin{array}{l}43.92 \\
62.72\end{array}$ & $\begin{array}{l}43.65 \\
42.93\end{array}$ & \\
\hline 粉行険查 & $\begin{array}{l}\text { 平均 } \\
S D D\end{array}$ & $\begin{array}{l}58.23 \\
61.09\end{array}$ & $\begin{array}{l}60.49 \\
63.57\end{array}$ & $\begin{array}{l}58.84 \\
59.18\end{array}$ & $\begin{array}{l}43.49 \\
41.30\end{array}$ & $\begin{array}{l}38.00 \\
36.45\end{array}$ & $\begin{array}{l}33.73 \\
35.96\end{array}$ & $\begin{array}{l}43.69 \\
40.69\end{array}$ & $\begin{array}{l}37.59 \\
34.69\end{array}$ \\
\hline 単脚起立検查 & $\begin{array}{l}\text { 平均 } \\
\text { S D }\end{array}$ & $\begin{array}{r}28.82 \\
4.30\end{array}$ & $\begin{array}{l}28.96 \\
3.97\end{array}$ & $\begin{array}{l}29.52 \\
\text { 2. } 63\end{array}$ & $\begin{array}{r}55.58^{*} \\
11.9\end{array}$ & $\begin{array}{l}29.77 \\
\text { 2. } 18\end{array}$ & $\begin{aligned} & 29.47 \\
& 2.95\end{aligned}$ & $\begin{aligned} & 29.88 \\
& 1.50\end{aligned}$ & $\begin{array}{l}58.59^{*} \\
6.78\end{array}$ \\
\hline
\end{tabular}

表 5 昭和 53 年度学校調查結果，平衡機能検查成績の相閣 総数 1855 名 スポーツテスト（右上）は 244 名 有意（p<0.001）の相関係数の子 を示す 学業成續総点は小学生 20, 中学生 25, 性別では男 1, 女 2 とする.

\begin{tabular}{|c|c|c|c|c|c|c|c|c|c|c|}
\hline & 学 年 & & & & & & & 学 年 & 性 別 & 体筒成續 \\
\hline 性 別 & & 性 別 & & & & スポーツ & $\begin{array}{l}\text { 渶動能力 } \\
\bar{\tau} \text { ス }\end{array}$ & -.279 & & .350 \\
\hline 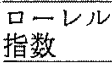 & -.146 & & 指一数 & & & テスト & 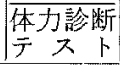 & .261 & .392 & \\
\hline 学業成績 & .230 & & -.086 & 学業成績 & & & & & & \\
\hline 体育成績 & & & -.127 & .340 & 体育成續 & & & & & \\
\hline 単脚起立 & .214 & & & .155 & .182 & 单脚起立 & & & & \\
\hline 步行検査 & -.082 & & & & & & 步行㭘査 & & & \\
\hline $\begin{array}{l}\text { 回枟检蒩 } \\
\text { ず和 }\end{array}$ & & & & & & & & 回枟検査 & & \\
\hline $\begin{array}{l}\text { 回転検查 } \\
\text { 角度 }\end{array}$ & -.187 & & & -.162 & -.091 & -.104 & .099 & & \begin{tabular}{|l|l|l|} 
角度 \\
\end{tabular} & \\
\hline $\begin{array}{l}\text { レールテ } \\
\text { スト }\end{array}$ & & & & .082 & .169 & .144 & & & & $\mid \begin{array}{l}レ ー ル テ \\
\text { スト }\end{array}$ \\
\hline $\begin{array}{l}\text { 平均台テ } \\
\text { ス下 }\end{array}$ & & & & & & .165 & & & & .197 \\
\hline
\end{tabular}

めた平均值の閒に有意差 $(\mathrm{p}<0.01)$ がみ上められたも のである。

7. 昭和53年度アンケート調查結果

1) アンケート回答の学年別, 性別比率
昭和53年度のアンケート調查で，澌問に対して「はい」 の答党のあったものの百分率を学年別, 性別反本人用質 問 $(1 \sim 7)$ を図 2 に, 担任用質問 $(8 \sim 15)$ を図 3 に示 t) 


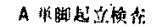

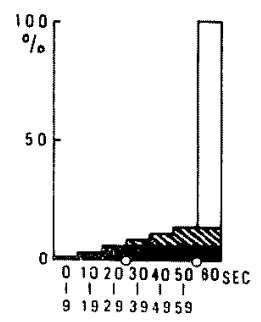

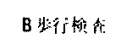

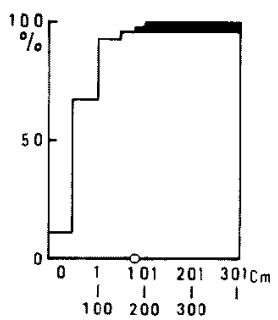

$C\left\llcorner-n+>_{1}\right.$

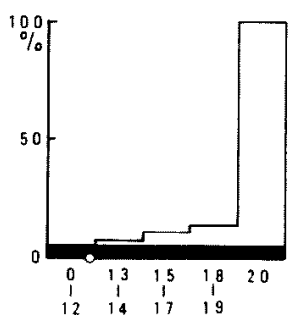

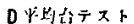

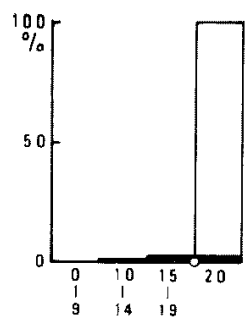

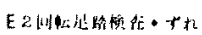

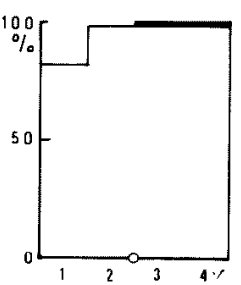

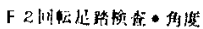

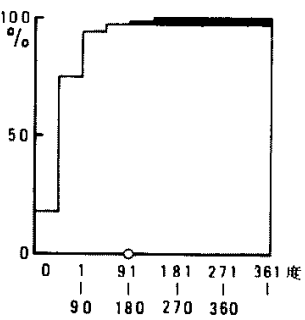

図 1 昭和53年度平衡機能検査成績累積分有图 ○活標準值, 黑い部分は異常者, 斜線は標準 值60秒とした異常者

\section{2）本人用質問之担任用算問の比較}

同じ種類の犋問に対する本人の答えと担任の答兑とを 比较する目的て $2 \times 2$ 分割表を作成し表 2 に示した。

両者の答えの閒の関係が有意上判定されたものは「中 耳炎の睡往（本人）」と「難聴（担任）」（p<0.05）,「乗物 酔」（本人之担任， $\mathrm{p}<0.001$ ), 「起立性調篃異常」(本人

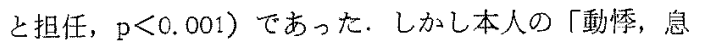
切れ」，「立ちくらみ」と担任のみた「起立調節異学」と の閻には有意な関係は得られな加った。

3）アンケート回答と学校調查, 平衡機能との関係

备質閶の答えを「いいえ」と「はいの2群に分け， それぞれの群の学校調查值と平貝機能椧查值の平均を比 較した. 有意差 $(\mathrm{p}<0.01)$ のったあののみを表 8 に 示す.
4) アンケートの回答と平衡機能検査異常出現率の関係 各質問で「いいえ」，「はい,「回答なし」の3群につ いて平衡機能検查での異常出現率を調查した. 先に示し た慓準值加ら外れるものが 5 種の検査のうらい扏か つでもあればすべて平衡機能検査異常とした.アンケー 卜の答えに対する平衡機能検查の正常者数，巽常者数、

暴常出現率を表 9 亿示す。

アンケートの答えと平衡能検査の正常, 異常の関係

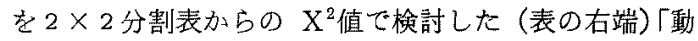

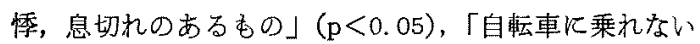
むの」（p<0.01），「課外スポーツをしないるの」（p< $0.01)$ ，「難㯖のあるもの」( $0<0.01)$ ，「転倒傾向のある もの」 $(\mathrm{p}<0.01)$, 「球技が得意でないあの」 $(\mathrm{p}<0.01)$, 估いられを平衡譏能異常出現率が有意に高かった。しか しその他の買問てはいい方」と「はい」の闲群に有意 差は認められなかった。

5）平衡機能異常者についてのアンケート学年别集計 5 種目の平衡機能检查のいづれが 1 つで香標準值から 外れた異常者についてのアンケート質閔て「はい」と答 光たすのの百分率を求めた。全体での百分率と平衡機能 異常を示した小学生の学年别百分率を本人用質問につい ては図 4 K，担任用啠問については图5に示す.

総数 2,037 名で平衡機能異常者は 452 名 $22.2 \%$ であ V男性 1,054名中 244名 23.1\%, 女性 963名中 208名 21. 2\%で男女差はなかった。

異常出現率法小学校 1 年生 $46.0 \% ， 2$ 年生 $24.5 \%$, 3 年生 $24.2 \%, 4$ 年生 $24.3 \%, 5$ 年生 $17.2 \%, 6$ 年 生 $8.4 \%$, 中学校 1 年生 $11.7 \%, 2$ 年生 $21.5 \%, 3$ 年 生 $12.9 \%$ あった.

\section{节}

慗

\section{1. 平衡機能検査 $の$ 種類}

一般に実施されている平衡機能検查法は，めまい，平 衡障害疾隐や神経疾患の診断に利用出来るように工夫さ れている，検査の種数は直立時の立ち直り反射をしらべ をRomberg テスト，身体の偏倚をしらべる正踏检查，

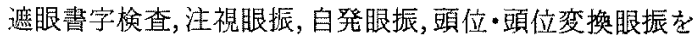
しらべる眼振検查, そして回転検査, 温度検查などの内耳 反応性検查, さbに視運動性眼振検查, 蓮動視標迫跡検査 などの視覚の閦与した眼運動検査で代表される

末梢前庭性障害や潹部知党異常による平衡障害では視 覚の働きで代償されるため，むっぱら視覚を除いた閉眼 や暗所開眼，また遮眼などの条件で検查がおこなわれ 
表 6 昭和53年度平衡機能検査正常，異常群の学校調查結果上他の平衡機能榆查成綪平均値

**估平均値差加有意 $(p<0.01)$ のもの

\begin{tabular}{|c|c|c|c|c|c|c|c|c|c|c|c|}
\hline 检查法 & 検查值 & $\begin{array}{l}\text { ロ } \text { ル指数 } \\
\end{array}$ & $\begin{array}{l}\text { 学業成 } \\
\text { 績 }\end{array}$ & $\begin{array}{l}\text { 体育成 } \\
\text { 縤 }\end{array}$ & $\begin{array}{l}\text { 単脚起 } \\
\text { 立 }\end{array}$ & $\begin{array}{l}\text { 步行检 } \\
\text { 查 }\end{array}$ & $\begin{array}{c}\text { 右 } 2 \text { 回転 } \\
\text { ずれ }\end{array}$ & $\begin{array}{l}\text { 右2回転 } \\
\text { 足踏角度 }\end{array}$ & $\begin{array}{l}\text { レール } \\
\text { デスト }\end{array}$ & $\begin{array}{l}\text { 平均台 } \\
\bar{T} \text { 大 }\end{array}$ & $N$ \\
\hline \multirow{2}{*}{$\begin{array}{c}\text { 単脚起立 } \\
\text { (秒) }\end{array}$} & 60 & 124 & 13 & 3.1 & & 41.6 & 1.2 & 37.0 & 18.9 & 19.9 & 1748 \\
\hline & 60末満 & $* * 129$ & $* * 11$ & $* * 2.6$ & & $* * 45.5$ & 1.2 & $* * 49.0$ & $* * 17.8$ & 19.4 & 276 \\
\hline \multirow{2}{*}{$\begin{array}{c}\text { 歩行検査 } \\
(\mathrm{cm})\end{array}$} & 130以下 & 125 & 13 & 3.1 & 56.4 & & 1.2 & 38.5 & 18.9 & 19.8 & 1983 \\
\hline & 131以上 & 124 & 12 & 2.9 & 51,1 & & 1,2 & $* * 62.9$ & $* *_{17.8}$ & 19.8 & 48 \\
\hline \multirow{2}{*}{ 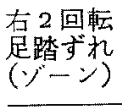 } & 2 以下 & 125 & 13 & 3,1 & 56.3 & 41.9 & & 38.9 & 18.9 & 19.8 & 1975 \\
\hline & 3 以上 & 126 & 14 & 2.9 & 55.0 & 47.9 & & 45.7 & 18.9 & 19.9 & 33 \\
\hline \multirow{2}{*}{$\begin{array}{c}\text { 在 } 2 \text { 回転 } \\
\text { 足等角度 } \\
\text { (度) }\end{array}$} & 135以下 & 125 & 13 & 3.1 & 56.4 & 41.6 & 1.2 & & 18.9 & 19.9 & 1982 \\
\hline & 136以上 & 127 & $* *_{11}$ & 2.8 & $* *_{51.7}$ & $* * 60.7$ & 1.19 & & 19.4 & 20.0 & 36 \\
\hline レールテ & 12末満 & 125 & 13 & 3.1 & 56.5 & 41.9 & 1.2 & 39.1 & & 19.9 & 1959 \\
\hline スト & 12 以上 & 129 & $* *_{11}$ & $* *_{2.4}$ & $* *_{49.5}$ & 46.1 & 1.3 & 41.2 & & 18.9 & 69 \\
\hline 平均台テ & 20 & 125 & 13 & 3.1 & 56.5 & 42.3 & 1.2 & 39.3 & 18.9 & & 1947 \\
\hline スト & 20 未満 & 122 & 13.8 & $* * 2.6$ & $* * 46.1$ & 53.4 & $* *_{1.4}$ & 50.4 & $* * 16.7$ & & 45 \\
\hline
\end{tabular}

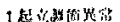
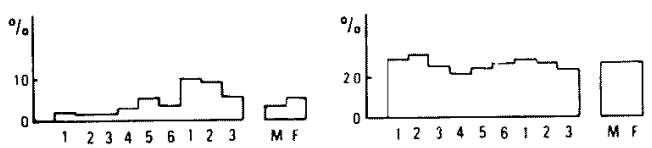

2 Gitf: . 닌

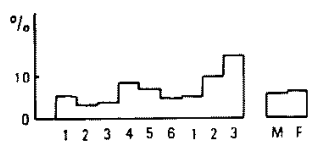

6 ift?t?

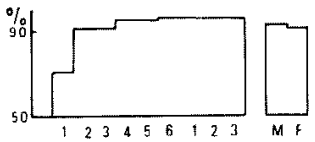

$316,64,2$
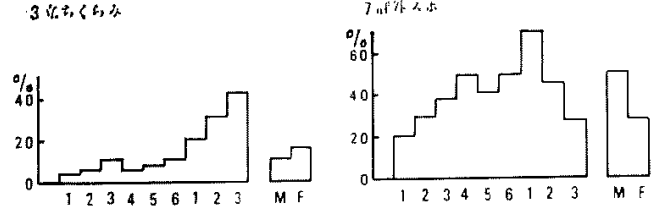

$$
4 \text { 婙物特 }
$$

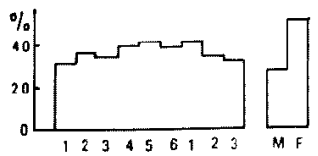

图 2 本人用アンケート学年别, 性別回答

(昭和53年度)

「はい」の回答者百分率, 横軸数字は小学校 中学校学年, M.F は男性, 女性
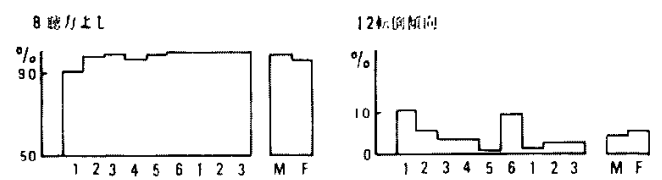

9 絽/1.上 L

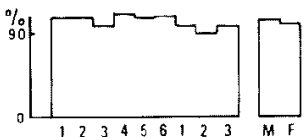

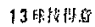
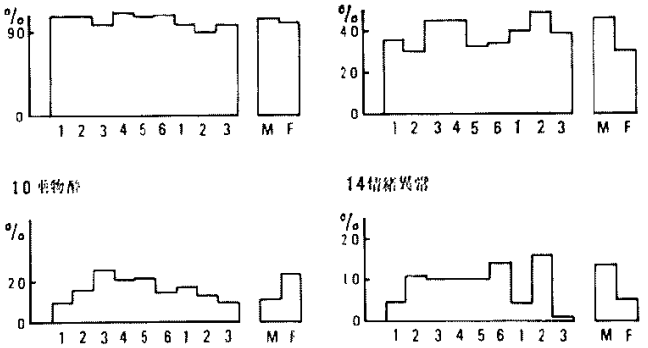

14 thin

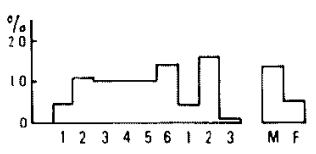

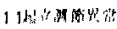

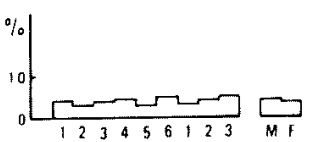

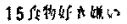

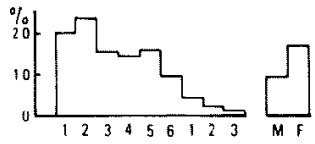

図 3 担任用アンケート学年別, 性別回答 (炤和53年度)

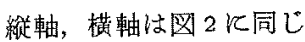


表 7 昭和 53 年度本人用, 担任用アンケートの関係

* $\mathrm{p}<0.05 \quad * * \mathrm{p}<0.01$ で有意のもの

A 5: 中耳炎の暨往格?

(本人)

8: 聴力は良い加?

(担任)

B 4：乘物酔は?

（本人）

10：乗物䣲は？

(担任)

C 1：起立調節異常は？

（本人)

11：起立調節異常は？

(担任)

D 2：動㥛息切れは？

(本人)

11：起立調節異常は?

(担任)

E 3：立ちくらみは？

(本人)

11：起立調節異常は？

(担任)

\begin{tabular}{|c|c|c|c|}
\hline $8-5$ & なし & あり & 計 \\
\hline 良い & 1408 & 509 & 1917 \\
\hline
\end{tabular}

\begin{tabular}{rrrr} 
わるい & 70 & 13 & 83 \\
\hline 計 & 1478 & 522 & 2000 \\
\hline
\end{tabular}

\begin{tabular}{cccc}
\hline $10-4$ & なし & あり & 計 \\
\hline なし & 1186 & 473 & 1659
\end{tabular}

\begin{tabular}{crrr} 
あり & 82 & 264 & 346 \\
\hline 計 & 1268 & 737 & 2005 \\
\hline
\end{tabular}

\begin{tabular}{cccc}
11 & なし & あり & 計 \\
\hline なし & 1865 & 60 & 1925
\end{tabular}

\begin{tabular}{rrrr} 
あり & 53 & 20 & 73 \\
\hline 計 & 1918 & 80 & 1998 \\
\hline
\end{tabular}

\begin{tabular}{cccc}
\hline $11+2$ & なし & あり & 計 \\
\hline なし & 1812 & 120 & 1932
\end{tabular}

\begin{tabular}{|c|c|c|c|}
\hline あり & 66 & 7 & 73 \\
\hline 計 & 1878 & I 27 & 2005 \\
\hline 11 & なし & あり & 棓 \\
\hline なし & 1670 & 261 & 1931 \\
\hline
\end{tabular}

\begin{tabular}{rrrr} 
あり & 59 & 14 & 73 \\
\hline 計 & 1729 & 275 & 2004 \\
\hline
\end{tabular}

\begin{tabular}{|cc|}
\hline 問 & 未記人 \\
\hline 5 & 32 \\
8 & 10 \\
\hline $\mathrm{X}^{2}=4.89^{*}$
\end{tabular}

\begin{tabular}{|rc|}
\hline 問 & 未記入 \\
\hline 4 & 29 \\
10 & 8 \\
$X^{2}=281.26^{* *}$
\end{tabular}

\begin{tabular}{|rc|}
\hline 問 & 未記人 \\
\hline 1 & 30 \\
11 & 8 \\
\hline $\mathrm{X}^{2}=107.88^{* *}$
\end{tabular}

\begin{tabular}{|cc|}
\hline 問 & 未記入 \\
\hline 2 & 29 \\
\hline
\end{tabular}

$\mathrm{X}^{2}=1.35$

\begin{tabular}{|cc|}
\hline 問 & 未記入 \\
\hline 3 & 30 \\
\hline$X^{2}=1.90$
\end{tabular}

古.

直立検査では近年直立持の重心動摇を電気的に記録す る方法が開発されている。重心棓 gravicorder を用いた Hirasawa ${ }^{93}$ の報告によれば，前方注視で耐足をそるえ 20秒間直立時の重心動摇の面積の各年粭における平均值 は6藏より8歳に至るまで急速に减少し，その後20歳迄 年齿と共保僅加減少するという。

直文時には Romberg 姿勢より片足立ちの方が安定が わるい，学龄期前でば左片足立ち10秒間起立の可能なも のは女子についてみると，4藏では開眼で $26.5 \%$, 閉眼 では $0 \%, 5$ 藏では閶眼で $72.5 \%$ ，閉眼で $20.0 \% ， 6$ 歳では開眼で $80 \%$ ，閉眼で 48\%であるという報告があ $3^{5}$.

Heath法レールテストによる報告で统小 中学生で年
每のテスト值の向上が明らかにされている8)。

われわれの棌用した検查方法はすでに報告したように 13), 身体の平衡関係与る視覚, 深部知觉, 前庭三半視 管の機能, 共同運動や湘定能力などの小脳機能が適当に 組み合わされた総合的平衡機能検查である，遊戯や体操 のように被検者方興味をもって容易に夷施出来るし，判 定方法が簡単である利点がある。

類似の組子合わ也检査として池松7 は千葉市の小・中 学校生 1,573名について閉眼20秒間の片足起立, 進眼で $6 \mathrm{~m}$ の直線上の歩行, 開眼で普通の早さでの平均台上の 步行の检査を実施した. 判定基準を定め検査の不成功率 は，小学生 835名では 29\%, 中学生 574名では 9\%, 全 林では $21 \%$ であったと報告している。

2. 平衡機能検查湘定值の比接 
表 8 昭和53年度アンケート回答と学校調查結果招よび平衡機能検查成績との関係 小学生で有意差（p<0.01）のある平均值を示す.

\begin{tabular}{|c|c|c|c|c|c|c|c|c|c|c|}
\hline 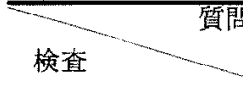 & & $\begin{array}{l}\text { ローレル } \\
\text { 指数 }\end{array}$ & 学業成績 & 体育成績 & 単脚起立. & 歩行檢榅 & $\begin{array}{l}2 \text { 回転足 } \\
\text { 踏ずれ }\end{array}$ & $\begin{array}{l}2 \text { 回転足 } \\
\text { 踏角度 }\end{array}$ & $\begin{array}{l}\text { レール } \\
\text { テスト }\end{array}$ & $\begin{array}{l}\text { 平均台 } \\
\text { テス卜 }\end{array}$ \\
\hline \multicolumn{11}{|l|}{ 本人アンケート } \\
\hline 1. 起立調節異常 & $\begin{array}{l}\text { なし } \\
\text { あり }\end{array}$ & & & $\begin{array}{l}3.09 \\
2.59\end{array}$ & & & & & & \\
\hline 2. 動㥪息切れ & $\begin{array}{l}\text { なし } \\
\text { あり }\end{array}$ & $\begin{array}{l}125.6 \\
130.6\end{array}$ & $\begin{array}{l}12,7 \\
11.1\end{array}$ & $\begin{array}{l}3.09 \\
2.63\end{array}$ & & & & & $\begin{array}{l}19.2 \\
18.0\end{array}$ & $\begin{array}{l}19.9 \\
19.5\end{array}$ \\
\hline 3.立ちくらみ & $\begin{array}{l}\text { なし } \\
\text { あり }\end{array}$ & & & & & & & & & \\
\hline 4. 乗 物 酔 & $\begin{array}{l}\text { なし } \\
\text { あり }\end{array}$ & & & $\begin{array}{l}3.11 \\
2.99\end{array}$ & & & & & & \\
\hline 5. 中耳炎既往 & $\begin{array}{l}\text { なし } \\
\text { あり }\end{array}$ & & & & & & & & & \\
\hline 6.自 転 車 & $\begin{array}{l}\text { のれない } \\
\text { のれる }\end{array}$ & $\begin{array}{l}129.0 \\
123.9\end{array}$ & & $\begin{array}{l}2.75 \\
3.10\end{array}$ & $\begin{array}{l}49.4 \\
57.1\end{array}$ & $\begin{array}{l}57.4 \\
41.1\end{array}$ & & $\begin{array}{l}61.8 \\
38.0\end{array}$ & & \\
\hline 7.課外スポーツ & $\begin{array}{l}\text { しない } \\
\text { する }\end{array}$ & & $\begin{array}{l}12.4 \\
12.9\end{array}$ & $\begin{array}{l}2.95 \\
3.25\end{array}$ & $\begin{array}{l}55.1 \\
56.6\end{array}$ & $\begin{array}{l}45.5 \\
36^{\circ} 9\end{array}$ & & & & \\
\hline \multicolumn{11}{|l|}{ 担任アンケート } \\
\hline 8. 難 聴 & $\begin{array}{l}\text { あり } \\
\text { なし }\end{array}$ & & & & $\begin{array}{l}49.9 \\
55.7\end{array}$ & & & $\begin{array}{l}63.7 \\
41.8\end{array}$ & $\begin{array}{l}18.0 \\
19.2\end{array}$ & $\begin{array}{l}19.2 \\
19.8\end{array}$ \\
\hline 9. 視 力 & $\begin{array}{l}\text { わるい } \\
\text { よい }\end{array}$ & $\begin{array}{l}120.6 \\
126.1\end{array}$ & & & & & & & $\begin{array}{l}17.3 \\
19.2\end{array}$ & \\
\hline 10. 乗 物 酔 & $\begin{array}{l}\text { なし } \\
\text { あり }\end{array}$ & & & $\begin{array}{l}3.11 \\
2.90\end{array}$ & & & & & & $\begin{array}{l}19.9 \\
19.6\end{array}$ \\
\hline 11. 起立調節異常 & $\begin{array}{l}\text { なし } \\
\text { あり }\end{array}$ & & & & & & & & $\begin{array}{l}19.2 \\
18.2\end{array}$ & \\
\hline 12. 枟倒傾吉 & $\begin{array}{l}\text { なし } \\
\text { あり }\end{array}$ & & & $\begin{array}{l}3.11 \\
2.62\end{array}$ & $\begin{array}{l}55.8 \\
52.3\end{array}$ & & & & $\begin{array}{l}19.2 \\
17.9\end{array}$ & $\begin{array}{l}19.8 \\
19.3\end{array}$ \\
\hline 13. 球技は得意 & $\begin{array}{l}\text { Wいえ } \\
\text { はい }\end{array}$ & & $\begin{array}{l}12.3 \\
13.0\end{array}$ & $\begin{array}{l}2.70 \\
3.70\end{array}$ & $\begin{array}{l}54.4 \\
57.5\end{array}$ & & & & $\begin{array}{l}19.0 \\
19.6\end{array}$ & \\
\hline 14. 情緒不安定 & $\begin{array}{l}\text { なし } \\
\text { あり }\end{array}$ & & $\begin{array}{r}12.9 \\
9.5\end{array}$ & $\begin{array}{l}3.12 \\
2.63\end{array}$ & & & & $\begin{array}{l}41.4 \\
50.5\end{array}$ & $\begin{array}{l}19.2 \\
18.7\end{array}$ & \\
\hline 15. 食物好き嫌い & $\begin{array}{l}\text { なし } \\
\text { あり }\end{array}$ & & & $\begin{array}{l}3.14 \\
2.74\end{array}$ & & & & & & \\
\hline
\end{tabular}

昭和53年度のわれわれの括こなった平衡機能検査測定 值の学年别の調查では, 飛行機型単脚起立の起立時間, 步行㛟查偏倚，2回転足踏検查偏位角度，レールテス卜 スコアではいづれ香高学年になるに隹って平均值の向上 と標準偏差の減少の傾问がみられた，しかし2回忶是踏 検査のずれと，学年により難易度の異る平均台テストで 泣学年差はみられなかった，男女差はいづれむわずかで あった．昭和52年度までの3 年間と昭和53年度の測定值
とを比較する上，多くの検查で僅かではあるが，測定值 に向上がみられた。これは被検者ならびル检査者の检查 实施にあたっての習熟によるものと考えられた。

3. 学校調植值の比校 ローレル指数の平均值な，前回の報告では，小学校6 仵生が最低值を示したが，昭和53年度では中学 1 年生が 最低值を示し，中学生では高学年になる彷い，小学生て は低学年になるに徉って增加している。また平均值では 
表 9 昭和53年度アンケート回答上平衡機能異常出現率

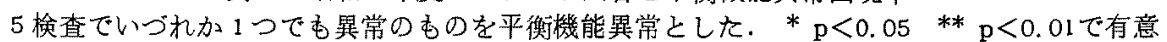

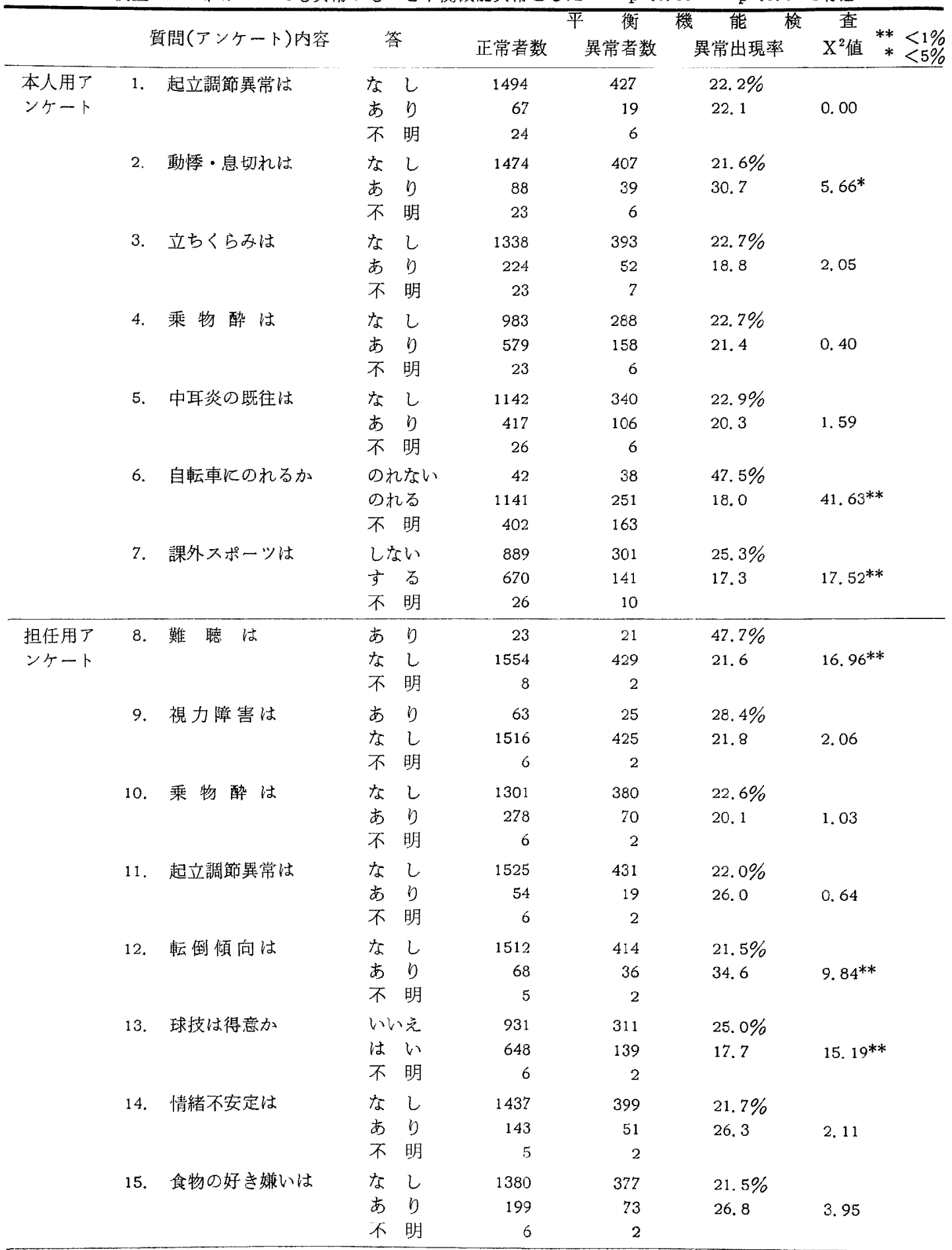




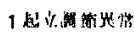

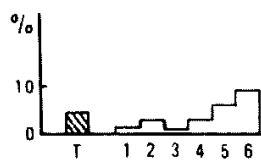

2 此陆. 步比九

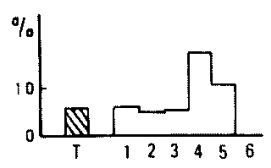

3 古的办

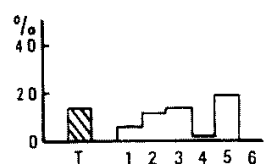

4 实物鲜

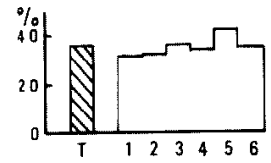

図 4 平衡機能異常者の本人用アンケート学年 別回答 昭和53年度小学生

「は心の回答者百分率 Tは平衡機能正常， 罣常竟含毛全学年平均，横軸数字侸学年

女性が男性よりやや高い，学業成續は小・中学生の間で の平均值は女性が男性よりやや高い，体老成績では僅か ではあるが逆に男性が女性より高い，小学校高学年と中 学生のスポーツテストの成績は楎動能力テス卜、体力䇏 断テスト共に総得点数は中学 1 校年生が最も低いのは㔻 慮される、運動能力テスト，体力診断テストの成緽はい られれ香体育成績とは逆に女性が男性より橃っていた。

\section{4. 学校調查俌と平衡機能検查値の相関}

昭和 53 年度調査の1,885名について学校調查結果と平 衡機能検弯成綪の相互の関係を示す相関係数マトリック 又から有意 $(\mathrm{p}<0.001)$ な相関係数加得られたものは次 の通りである。

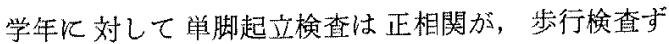
れ，2回転足踏検查偏位角度は負相関があり，いづれも 年秢と共に㭘查值の向上がみとめられた，ローレル指数 に対しては，学年，学業成績，体育成績がいつれむ負相 関を示したが，学業成績は小学校，中学校の総得点差を
8 纯小上L

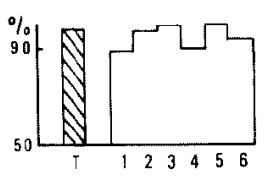

9 㫛光上 L

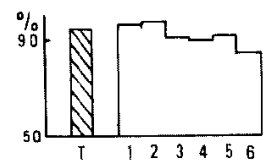

10 程物

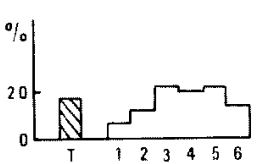

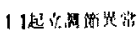

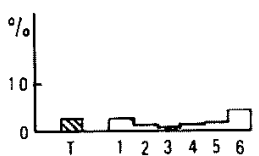

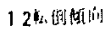

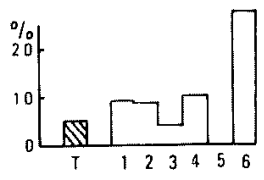

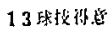

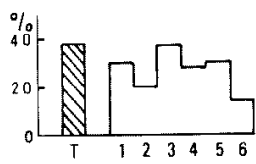

14 情背奖滥

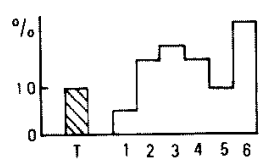

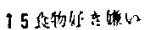

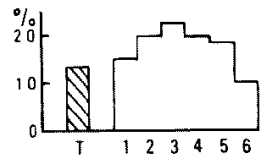

図 5 平衡機能異常者の担任用アンケート学 年別回答 昭和53年度小学生

縦軸，横輔は図 4 K同し

考慮していないので除外して考党ねばならない。しかし 学年と相関のない体育成績と学業成績とは正相関を示京 ことから, 学業成精と单脚起立, レールテストとの正相 関，2回枟足踏検査偏位角度との負相関は学に学年との 相関のみでないものと考えられる.

体育成績はローレル指数と負相関を示すことから肥渵 傾向者は体充成績が低下すると考克られる。体育成績に

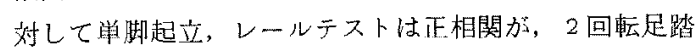
㭘查偏位角は負相関がみとめられ，これら平衡機能のよ いものは体育成䋶も鼠いといえる。一方学業成績之平衡 機能执よび体育成績との正相関加ら平衡機能の良いもの は学業成績芓良いといえよう。

昭和52年までの成縝で 2 回転足踏検查の右回転と左回 枟化嵪い正相関がみとめられたので昭和53年度は右回 枟のみでそれを代表させた。

平衡機能检查相互の相関については，立ち直りをしら ヘる単脚起立が，偏筒完しらベるレールテスト，平均台 
テストと正相関が，また半規管刺激も加わる2回忶足踏

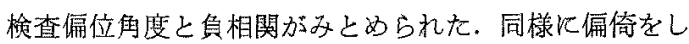
らべる歩行検査と半規管制激を加えた 2 回転足踏険查扁 位角度と正相関がある。したがって立ち直り，偏倚，半

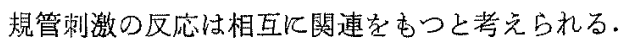

平均台テストは単脚起立，レールテストといつれも正 相関が認められた。平均台は学校常備されているので 他施設での検查の追試は容易であるう。

244名のスポーツテストの成績では学年に対して体力 テストは正相関が，運動能力テス卜は負相関が得られ た.な持体力診断テストと運動能力テス卜とは高い正相 関がみとめられた，運動能力テス卜は体育成績と正相関 を示し，また体力診断テスト甠女性の成積が良い。

5. 平衡機能㭘查異常の判定

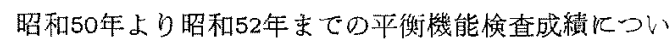
て累穔分布図をつくり，测定值のわるい小数群を除外し た標潐值を正常值として報告した，昭和53年度の平衡譏 能㭘查成縝は昭和 52 年までの成繢よりいずれる良く標染 值にみたない異常者の比洆は減少した。

すなわ立脚起立㭘査の標準値は昭和53年度は60犁上 定め異常者は $13.6 \%$ である。昭和52年までの測定上限 は30秒までであったため標準值は30秒で，この時の異常 者は $6.7 \%$ でであった。な招昭和53年度の30秒未满は5.9 \%である。

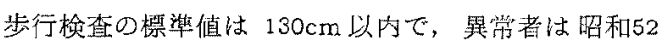
年までは $10.0 \%$ 対し昭和53年度は $2.4 \%$ である。

レールテストの標染值は12以上で異常者は昭和52年ま では $7.7 \%$ 茂し昭和53年度は $3.4 \%$ である。

2 回枟足踏検查の標準值はずれが 2 ゾーン以内，偏位角 度が $135^{\circ}$ 以内であり，ずれは，昭和52年までは右回枟 $1.5 \%$, 左回転 $1.8 \%$ K対し 昭和 53 年度は $1.6 \%$ 異常 者が，偏位㑇度では，昭和52年までは右回転 $8.7 \%$, 左 回転 $8.8 \%$ 亿対して昭和 53 年度は $1.8 \%$ 異常者がタと められた。

昭和53年汇新しく実施した平均台テストの祭準值休 20

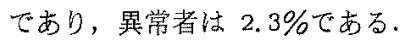

以上の判定規準征い各検查のいずれか一つでも異常 の場合平衡機能異常者として異常出現率をしらぶた。昭 和53年度の成績では $22.2 \%$ ですり 舅性 $23.1 \%$, 女性 $21.2 \%$ であった，小学生では 1 年生 $46.0 \%$ と最も高く, 学年と共減少し最低は6 年生 $8.4 \%$ ですった。学生

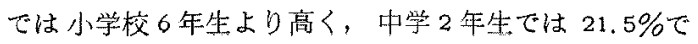
あった。

\section{6. アンケートの解析}

昭和53年度のアンケート調查の特徽は，質問項目をし ぼりままた本人用と担任用の双方を实施したことにあ る.

中耳炎の朁往（本人用）は小・中学生とも飞26\%であ るの対して, 難聴（担任用）は最高，小学校 1 年生 8 $\%$, 最低, 中学生 $1 \%$ で低い。

視力障害 (担任用) は最高, 中学 2 年生 $11 \%$, 最低, 小学校 4 年生 $1 \%$ で難聴よりpや高く，小学生平均 $3 \%$ と中学生平均 $8 \%$ の差は有意 $(\mathrm{p}<0.01)$ であった.

「長時間立っていると気持が悪くなるか」の質問に対 して本人の答えでは最高は中学校 1 年生 $9.9 \%$ であり, 小学生平均 $3.1 \%$ と中学生平均 $8.2 \%$ 差は有意 $(\mathrm{p}<$ 0.01）であった，女性 5\%と男性 3\%の差は有意ではな かった. しかし担任の答えでは小学生平均 3.4\%, 中学 生平均 $4.2 \%$ であ, 小・中学生別, 性別とも飞有意差 㹥得られな⿰力った。

乗物酔いの本人の答えでは小学校 5 年生 $41.7 \%$ が最 高であり，中学校 3 年生まで次第汇減少する. 小学生平 均 37\% 女中学生平均 36\%では差がないが女性 52\%は 男性 $28 \%$ よ 有意 $(\mathrm{p}<0.01)$ 飞多い，担任の答えでは 本人の答兄上り低く最高蛙 小学校 3 年生 $25.4 \%$ で, 小 学生平均 $18 \%$, 中学生平均 $13 \%$ であり, 同じく女性 $23.2 \%$ 男性 $11.5 \%$ 上り有意 $(\mathrm{p}<0.01)$ 飞多い。

動悸, 息切れ性小学生平均 $5.4 \%$ 上り中学生平均 9.4

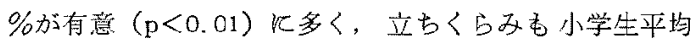
$8 \%$ 上り中学生平均 $32.3 \%$ 品同しく有意 $(\mathrm{p}<0.01) \mathrm{K}$ 多い，共に中学生では学年が進むにつれて増加し最高は 中学校 3 年生で, 動雬息切れでは $14.6 \%$ ，立ちくらみ

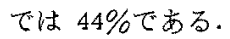

動悸，息切れでは男性 6\%，女性 7\%で性差はない が，立ちく占みでは女性 17\%はは男性 11\%より有意( $\mathrm{p}<$ 0, 01) 江多い

「走る時転でやすい」は小学生低学年飞多く学年が進 到と減少するが小学校 6 年生のみ $9.3 \%$ と多いのは特異 である. 小学生平均 $6.0 \%$ 性中学生平均 $2.3 \%$ 上り有意 $(\mathrm{p}<0.01)$ 飞多いが性差はない.

「自転車に乘れる加」の澌問は小学校 4 年生以上を対 象としたが，小学校低学年でも記入するものが多く参考 まで四标した。学生平均 93\%上中学生平均 $97 \%$ の

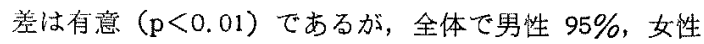
93\%の差柱有意でない.

「課外スポーツをやるか」の質問では小学校低学年で 
は学年とと屯に增加し，小学校 4 年生以後㽬打 万にな り, 中学校 1 年生 $69.7 \%$ は最高でその後は急速江減少 する. 小学生平均 $38 \%$ 上中学生平岣 $48 \%$ の美, 男性 $50 \%$ と性 $29.8 \%$ 差恃共に有意 $(\mathrm{p}<0.01)$ である.

「球技が得意」かの犋問は学年任特徽的なこ上はない 吕，男性 $46 \%$ は女性 $31 \%$ 上り有意 $(\mathrm{p}<0.01)$ 亿多い。

「勉強ざらい，根気がない，登校拒否など」の問題児 飞ついては, 小学生平均 10\% 上中学生平均 8\%の閒飞 差はない，多い学年は小学校 6 年生 $14 \%$ ，中学校 2 年 生 $17.7 \%$ で，少い学年は小学校 1 年 中学校 $1 \cdot 3$ 年 生である、男性 $13.8 \%$ は女性 $5.4 \%$ 上り有意 $(\mathrm{p}<0.01$ ( k多い.

「給食の食べ残し」は小学生低学年飞多く, 学年が淮 むと共に淢少する。学生平均 $16.7 \%$ は中学生平均 2.7\%より，末た女性 17\%は男性 $9.9 \%$ 上り有意 $(\mathrm{p}<$ $0.01)$ K多い.

同種の質問に対する本人と担任の答えを $2 \times 2$ 分割表 加ら X值で検定して，「乘物醉い」，「長時間立っている と気持がわるくなる」について危険率 $0.1 \%$ で，中耳炎 の睡往（本人）と難聴（担任）とは危険率 $5 \%$ で有意で あった。

し加し起立時異常（担任）上動㻑，息切れ，立ちくら み（本人）とに対する答元の間には有意性は認められず 異椞のものと考えられた。

7. アンケートの答えと学校調查值, 平衡機能検查値の 開係

アンケートの答えを「はい」と「いいえ」の2群敒分 け, それぞれの群の学校調查值平均之, 平衡機能検查值 平均を求め, 2 群間で平均值に有意差 $(\mathrm{p}<0.01)$ を䇛 めるもののみを検討した。

ローレル指数では動情，息切れがする委の130.6，自 転車にのれない129.0が高く，肥満傾向であり，視力が わるいもの120.6は渄型傾向である。

学業成績では動悸, 息切れがするもの, 課外スポーッ をしないすの，球技が得意でないものが劣り，特炕情緒 不安定の問題览は成縝がわるい。

体育成績についてはアンケート質閭に関係のあるもの が多い，起立時の異常，動悸，息切礼がする，乘物醉 い，転倒傾向，情緒不安定，食物の好き嫌いのあるもの はいづれむ成績が悪い。また自転車に乘れない，球技が 得意でないものも悪い。

平衡機能検查では立ち直り反射を主とする単脚起立赖

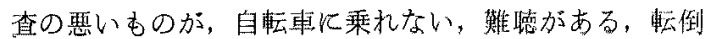

傾向夰ある，球技が得意でないあのに多い，

主として偏筒をしらべる検査の中で，自転車とのれな いもの, 新外スポーツをしないものが步行検亘の成績が わるいがレールテスト，平均台テストではそ礼らの関係 はない。

一方，勘雲，息切れ，蜼㯖，転倒傾问のあるものはレ 一ルテスト、平均台テストの成績がわるいが歩行㭘查て はみとめられない、レールテストでは視力がわるい，起 立調節異常（担任の答无）, 球技が得意でない，情緒不 安定のものが成綪がわるいが，平均台テストではそのよ るな関係は得られない。

歩行検查, レールテス卜，平均台テス卜は互に類似儿 た検盉法であり，特溪 2 者はその傾向があるが，細部 では違いがある・アンケート結果と関孫の樑いレールテ ストでは，視覚、聴覚，平衡党，連動の巧みさ，心理的 安定，心・循環調節機能など多面的要素が抽出されるも のと考えられる。

回伝刺激の加わ元られた 2 回転足踏検查では, 立ち直 り，暻倚の検省上異り，自転草に乗れない，難聴，情緒 不安定のもので回転検査偏位角度の成績がわるい。しか し回転検査のずれれついてはアンケートとの関係はみと められない。

乗物酔いについては本人の答えでは平衡機能検查成績 と関係がなく，担任の答えでわずか汇平均台テスト成績 のみが悪い。

アンケート回答上の関保からみて，平衡機能を調べる 5 㮔の検査はそれぞれ異質の翼常を捕えている向のとし て意義が認められた。

8. テンケートの答え之平衡機能買常者との関係

5 種の平衡㙨能㭘查について全体の約 $10 \%$ 成積不良 者を除く目的で標淮值を定めた。

しかし判定を容易にするため 10\%除外は敩密ではな 々，また之の後の検查者，被㭘者双方の検查法の習熟の ため祭準值から外される異常者の出現莎は減少した。

この標洮值の判定法に基いて 5 種の検査のいづれが 買常があ机恬平衡機能異常者上してみると昭和53年度調 禁では $22.2 \%$ 巽常出現彎であった。

アングートの答えの「いいえ」「はい」の2群につい て平衡機能界常出現率在しらべ， $\mathrm{X}^{2}$ 检定で有意な関係 が得られたもののみを抽出した。

自転車に乘れない，課外スポーツをしない，難聴があ る，枟倒傾问がある，球技が得意でないなどのものはい 方妃危険率 $1 \%$ で，動樰・息切机がするものは危険率 
$5 \%$ で平衡機能異常出現率が有意汇高い。

しかしその他の質問については平緦機能異常出現率と の関係岋みとめられていない。

今後この判定基蕉沉よる平衡機能翼常者のより精密な

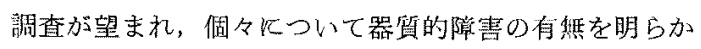
にして，学校教育の資料上すがきであると考光られる。

この観点加ら小学生の平衡機能異常を学年别飞分け， そのアンケートの答党をしらべた。

先に示した小学生総数 1,556 名の学年别アンケート答 亲と比較して平衡機能異常の小学生 378 名の学年別アン ケート答えが 2 倍以上を示したものは次の通りである.

（）内の数子は学年での平衡機能異常者の签え百分率 上，全体の答光百分率を示す

1）長い間立っていると带持が悪くなるものは6年生に 多い（本人の答えでは 9.5:4.4，担任の答えでは $9.5: 4.4)$.

2）動秄，息切狄は 4 年生飞多い(17.5:8.5).

3) 立ちく占みは 5 年生飞多い (18.9:7.8).

4) 走るとき転びやすいものは 4 年生 (11.2:3.5) と 6 年生 (28.5:9.3) K多い.

5）球技の得意なも杂の゙ 6 年生飞少ない(14:34). その他平衡機能異常者群《は炏の様な傾向当多与れ た.すなわち中耳炎の既往沬 6 年生 $(42: 25.6)$ 飞多 い. 視力のよいものが 6 年生 (85；97) K少ない. 情緒 不安定のものが 4 年生 $(18.7$ 10) と6年生 $(23: 16)$ 飞多小，給食の食べ残しが 3 年生 $(23: 16)$ 飞多い。

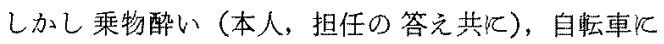
莱れる，課外スポーツ，恥力障害については平衡機能異 当者で特徽はみられなかった。

以上のことから平衡機能異常と判定された場合, 特厄 小学校高学年で, 起立性調箕障害 (6 年生), 心・犆環系 譈害( 4,5 年生), 中耳炎(6年生), 視力障害 (6 年生), 情緒障書（ $4 ， 6$ 年生）などの原因について精相を必要 とすると考えられる。

$$
\text { ま と } め
$$

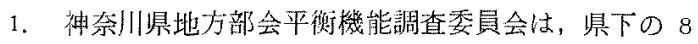

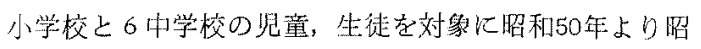
和153年まで 4年間に，8,592名の平衡機能模查と，乙狄 飞関係する事項の調查を实施した。

2. 平衡機能検查は飛行機型単脚起立, 歩行梌查, 2 回 転足踏检查，レールテスト，平均台テストの5種を扢こ ない，その判定基準を示した。
3. 各検查法の成續を多面的に解析した結果, これらの 检查は異る方向から平衡機能を明らかにするためいつれ あ意味があると考えられた，検植により得られた情報 は，同時飞実施したアンケート調查による内耳僟能，視 覚, 小脳性運動機能, 自律神経機能, 心循環采機能, 精 神医学的機能などと関保が少なくないことが示された。 4. 今後これらの調查結果を利用して, 児童生徒の葉団 的平衡機能検㭗加普及し，学校教育の向上に役立つこと を希望する。

\section{参考文献}

1) 日本学校保健会: 運動機能蚞查, 健康の評価のた的 の試み, 日本学校保健会, 東京 1-102, 1979.

2) X部省体育局: 昭和50年度体力, 運動能力調盗報告 裙 1975 。

3) Goetzinger $C P$ : A re-evaluation of the Heath railwalking test. J Educational Research 54; 187-191, 1961.

4) 木下 勇, 加藤直則, 田中晴人, 首藤 贵, 箖 舜 论，山田憲吾，茾形高明，山本博司，手束昭胤，片 山幸俊，田村大司，中川幸夫，竹内縝一. 小林 刀:

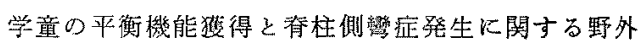
調管，中部整災誌 13(5):883-884，1970.

5) 高橋资次: 学校保健テキスト, 南山堂 東京 $4-32$, 1970.

6) 池松武之亮：学童乙平衡機能 炤和 47 年度全国学校 保健学校医大会誌 p 15, 1972.

7) 池松武之兑：学校保健に括ける罗與咽喉科医の責務 かが (2): 10-12，1972.

8) 池松武之亮：学童之平兽機能 千葉䀧医師会蛝 24 (11): 42-45, 1973.

9) Hirasawa $Y$; Study on human standing ability. Agressologie $14 \mathrm{C}: 37-44,1973$.

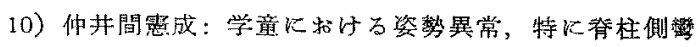
症について 中部整留誌 $17(1): 1+19 ， 1974$.

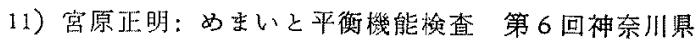
学校保侹学会抄録 p 18, 1975.

12) Mulch $G$, Petermann $W$ : Influence of age on results of vestibular function tests. Review on literature and presentation of caloric test results. Ann Otol Rhinol Laryngol 88 (Suppl 56 No 2 Part 2): 1-17, 1979.

13）范木元秋，德增厚二，野村公政，宮原正明，钣田す 
すむ，楠 好子，種元春洋，士田陽一：神奈川県児

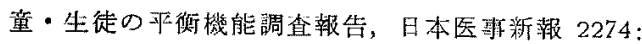
43-49, 1977.

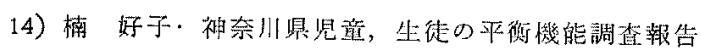
(第 1 報) 第 9 回神奈川臬学校保健学会抄録 33-39, 1978.

15）荒不元秋，德增厚二，影村公寿，宮原正明，飯田

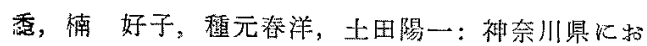
ける児童扣よび生徒の平衡機能の調查（第1 報）日 耳鼻 $81: 797-803,1978$.

16）野村公寿，荒木元秋，德增厚二，宫原正明，飯田 㴽，楠好子，種元春洋，士田隄一：神奈川県に和 ける児童和上び生徒の平衡機能の調查（第2 岝）日 耳鼻 82：248-254，1979.

17）宮原正明，荒木元秋，德增厚二，野村公寿，飯由 秋，楠 好子，種元春洋，士田陽一：补系川县に和 ける児童括よび生徒の平衡機能の調查（第 3 報）日 耳-䊩 83: 133-139, 1980.

18) Heath $S R$ : The military use of the railwalking test as an index of locomotor coordination. Psychological Bulletin 40: 282-284, 1943.

19) Heath $S R$ : Clinical significance of motor defects, with military implications. Am J Psychol 57: 482-499, 1944.

20) Proud $P$ : Heath rail test. Dizziness and vertigo edited by Spector, M. Grune and Stratton, New
York p. 97-98, 1967.

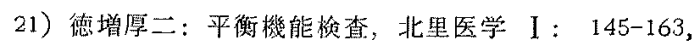
1971.

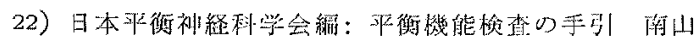
堂 東京 1-198, 1976.

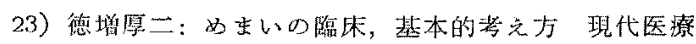
$10(9): 1123-1129,1978$.

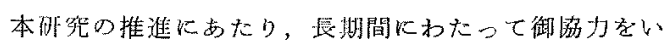
たたいた各委員会，学校ならび成俕者心深く感謝の意 袁捧げる。

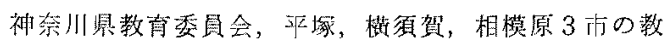
热委責会学校保健課,

平塚方松原，南原，崇善，土屋各小学校，金旭，大

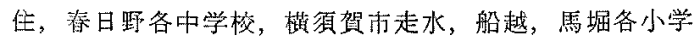

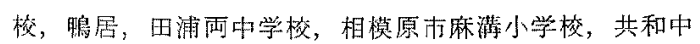
学恔,

科研化学株式会社学術部ならびル電箅室,

神䋈川罧医師会前事務局長浅田三郎氏，

本研究の一部は神祭川罢教育委員会委託研究損に上り 援助堂受けた。

(原稿受的照和 55.5.8日)

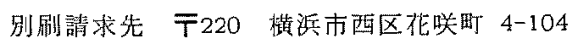

神奈川罢医師会館内 日耳鬼神奈川県地方部会 